\title{
INSULIN-LIKE GROWTH FACTOR BINDING PROTEIN 3 (IGF-BP3) INHIBITS ESTROGEN-STIMULATED BREAST CANCER CELL PROLIFERATION
}

\author{
Susan E. Pratt and Michael N. Pollak \\ Lady Davis Institute of McGill University and the Jewish General Hospital \\ Montreal, Quebec, Canada H3T 1E2
}

SUMMARY: We have recently demonstrated that exposure of MCF7 cells to antiestrogens in vitro results in both accumulation of IGF-BP3 in media and reduced mitogenic responsivity to IGFs (Cancer Res. 53:5193-5198). We show here that MCF7 cell proliferation in steroidstripped, serum containing media is significantly attenuated by rhIGF-BP3 $(\mathrm{p}<0.05)$, with a maximal $40 \%$ inhibition of serum stimulated growth achieved by $6.25 \mathrm{nM}$ IGF-BP3. $10^{-10} \mathrm{M}$ estradiol $\left(E_{2}\right)$ significantly stimulated MCF7 proliferation, and co-incubation of estrogen containing cultures with 50nM IGF-BP3 resulted in significant attenuation of the estrogenstimulated proliferation $\left({ }^{3} \mathrm{H}\right]$ thymidine incorporation: $\mathrm{E}_{2}, 147 \pm 18 \%$ of control; $\mathrm{E}_{2}+$ IGF-BP3, $111 \pm 18 \%$ of control, $p<0.05$ ). These results demonstrate antagonism of steroid stimulated proliferation by an IGF binding protein and are compatible with the hypothesis that antiestrogeninduced accumulation of IGF-BP3 in the conditioned media of MCF7 cells contributes to the cytostatic action of these drugs.

Most breast cancer cells express the type I insulin-like growth factor (IGF) receptor $(1,2)$ and are mitogenically responsive to IGFs. Six IGF binding proteins (IGF-BPs) have been identified and are believed to play a role in the modulation of IGF actions and bioavailability $(3,4)$. In tissue culture, breast cancer cells secrete IGF-BPs into the media (5-7) and we have recently demonstrated that accumulation of IGF-BP3 in the conditioned media of type I IGF receptor positive, estrogen receptor positive MCF7 human breast cancer cells is specifically down-regulated by estrogen and up-regulated by antiestrogens (8). This effect of antiestrogens may be related to the observation that antiestrogen treatment of MCF7 cells results in a reduction of both serum and IGF-I stimulated cell proliferation which correlates with accumulation of IGF$\mathrm{BP} 3$ in the conditioned media (8).

IGF-BP3 has been shown to inhibit $(9,10)$ or potentiate $(11,12)$ IGF action in various experimental systems. To determine whether an antiestrogen-induced increase in IGF-BP3 concentration could contribute to the antiproliferative actions of antiestrogens, we studied the effects of exogenously added hrIGF-BP3 on baseline and estrogen-stimulated MCF7 cell proliferation. 


\section{MATERIALS AND METHODS}

MCF7 cells were cultured as previously described (8). Briefly, cells were plated and maintained in phenol-red free DMEM supplemented with $5 \%$ dextran-coated charcoal stripped fetal calf serum (DCC-FCS) for 3 days prior to treatment to eliminate endogenous steroids. Treatment was continued in the same media which was supplemented with human recombinant IGF-BP3 (produced in E. coli, a generous gift from Chris Maack, Celltrix Pharmaceuticals, Santa Clara, California) and 17B-estradiol (Sigma) where indicated. MCF7 cell proliferation was evaluated by $\left[{ }^{3} \mathrm{H}\right]$ thymidine incorporation after 2 days of treatment, or by cell number determinations after 7 days of treatment. Statistical comparisons of treatment conditions were done using the Mann-Whitney U test.

\section{RESULTS}

The addition of 50nM IGF-BP3 to MCF7 cell cultures grown under estrogen free conditions (phenol red-free media supplemented with 5\% DCC-FCS) resulted in a significant $38 \pm 14 \%(p<0.05, n=9)$ reduction of DNA synthesis as measured by $\left[{ }^{3} \mathrm{H}\right]$ thymidine incorporation after 2 days of treatment (figure 1A). The effects of exogenous IGF-BP3 on MCF7 cell proliferation were confirmed by the determination of cell number after 7 days of growth under the same conditions (figure 1B). Control cell cultures (5\%DCC-FCS) demonstrated a 4.2-fold increase in cell number over 7 days which was significantly reduced (2.4-fold increase in cell number; $p=0.04, n=4$ ) in companion cultures grown in the presence of 50nM IGF-BP3. The addition of $0.1 \mathrm{nM} 17 \mathrm{~B}$-estradiol resulted in a significant stimulation of DNA synthesis and cell proliferation when compared to the estrogen-free control. A significant reduction of estrogen-
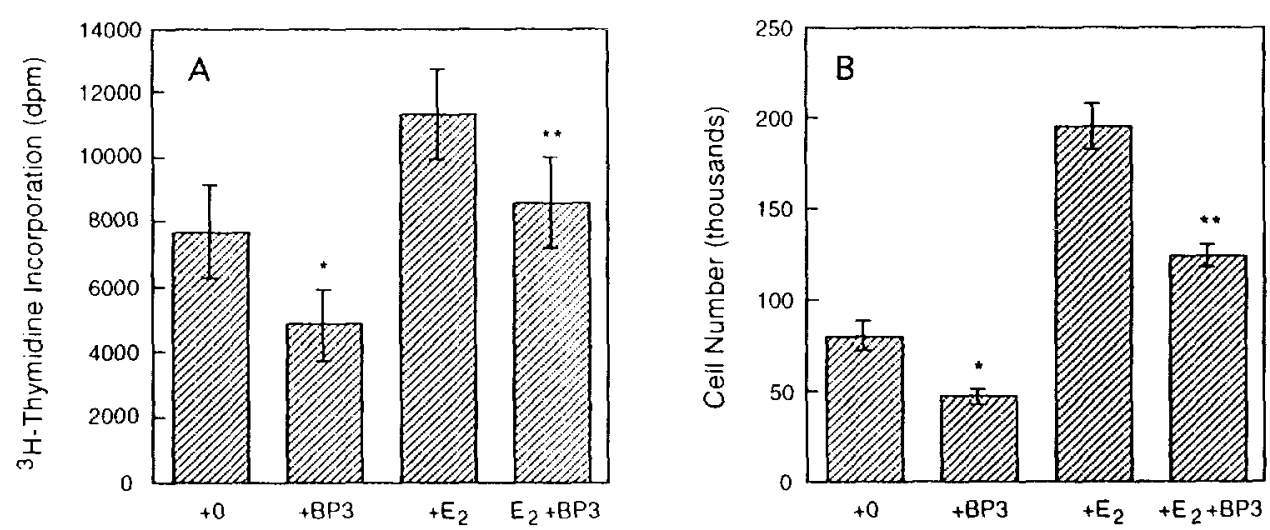

FIGURE 1. IGF-BP3 inhibition of baseline and estrogen-stimulated MCF7 cell proliferation. In companion experiments, MCF7 cells were cultured in 5\% DCC-FCS supplemented media with or without $50 \mathrm{nM}$ IGF-BP3 in the absence or presence of $0.1 \mathrm{nM} 17 \mathrm{~B}$-estradiol as described in Materials and Methods. A. $\left[{ }^{3} \mathrm{H}\right]$ thymidine incorporation of MCF7 cells was evaluated after 2 days of treatment. Data are expressed as the mean dpm/well \pm SEM, $(n=9)$. B. After 7 days of treatment, cell number determinations/well were made $(\mathrm{n}=4)$ for each condition. MCF7 cell number/well on day 0 of treatment was 18,800 \pm 1400 . ${ }^{*} \mathrm{p}<0.05$ for control $(+0)$ vs. IGF-BP3 treated cells $(+\mathrm{BP} 3) ;{ }^{* *} \mathrm{p}<0.05$ for estradiol $\left(+\mathrm{E}_{2}\right)$ vs. $\mathrm{E}_{2}+\mathrm{BP} 3$ treated cells. 


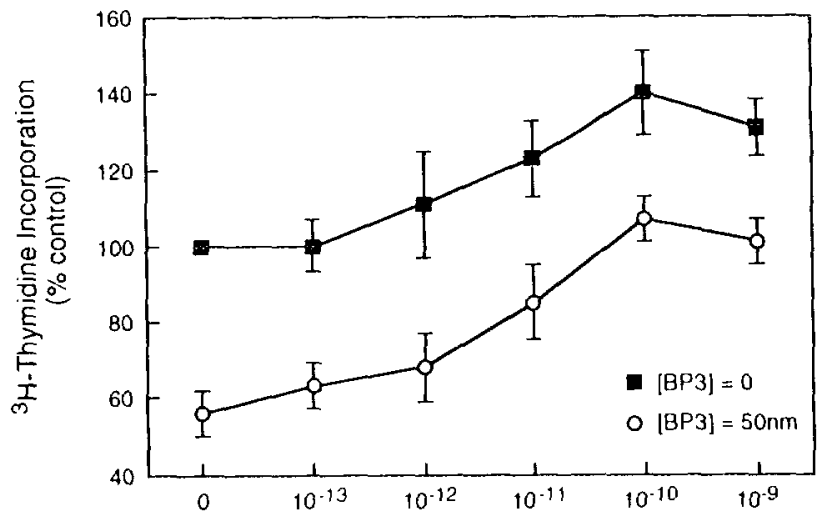

$\left[E_{2}\right], M$

FIGURE 2. Inhibition of 17B-estradiol stimulated MCF7 cell proliferation by IGF-BP3. MCF7 cells were cultured with increasing concentrations of $17 \mathrm{~B}$-estradiol in the absence or presence of $50 \mathrm{nM}$ IGF-BP3 and evaluated by $\left[{ }^{3} \mathrm{H}\right]$ thymidine incorporation. Data from 4 paired experiments are expressed as the mean percentage \pm SEM of the value obtained in the estrogen-free, IGF-BP3free (control) condition.

stimulated $\left[{ }^{3} \mathrm{H}\right]$ thymidine incorporation $(\mathrm{p}<0.05, \mathrm{n}=9)$ and cell number $(\mathrm{p}=0.02, \mathrm{n}=4)$ was observed with the addition of 50nM IGF-BP3 to estradiol containing media (figure 1A and B).

In our experimental system, the stimulation of MCF7 cell proliferation by estrogens occurs in a dose dependent manner with maximal stimulation of $\left[{ }^{3} \mathrm{H}\right]$ thymidine incorporation observed in the presence of $0.1 \mathrm{nM} 17 \mathrm{~B}$-estradiol (figure 2). In paired studies, the addition of 50nM IGFBP3 decreased estrogen-free MCF7 DNA synthesis by $44 \pm 6 \%$, and $\left[{ }^{3} \mathrm{H}\right]$ thymidine incorporation was similarly reduced at all estrogen concentrations. The estrogen dose-response curves in the presence and absence of IGF-BP3 run parallel to one another indicating that IGF-BP3 treated cells remain estrogen responsive, however their responsiveness is greatly diminished and never significantly exceeds levels of $\left[{ }^{3} \mathrm{H}\right]$ thymidine incorporation observed under estrogen-free, IGFBP3-free conditions.

Growth inhibition by IGF-BP3 occurs in a dose dependent manner (figure 3) both in the presence and the absence of estrogens. In this experiment, $\left[{ }^{3} \mathrm{H}\right]$ thymidine incorporation under estrogen-free conditions was reduced to $57 \pm 9 \%$ of control by IGF-BP3, with half-maximal inhibition occurring at an IGF-BP3 concentration of $3 \mathrm{nM}$ (figure $3 \mathrm{~A}$ ). In the presence of $0.1 \mathrm{nM}$ $17 \mathrm{~B}$-estradiol (figure $3 \mathrm{~B}$ ), proliferation was stimulated to $178 \pm 13 \%$ control in the absence of IGF-BP3, but only to $133 \pm 7 \%$ in its presence.

\section{DISCUSSION}

While there is evidence that there are relationships between the pathways by which estradiol and IGFs stimulate proliferation in estrogen receptor positive breast cancer cells 

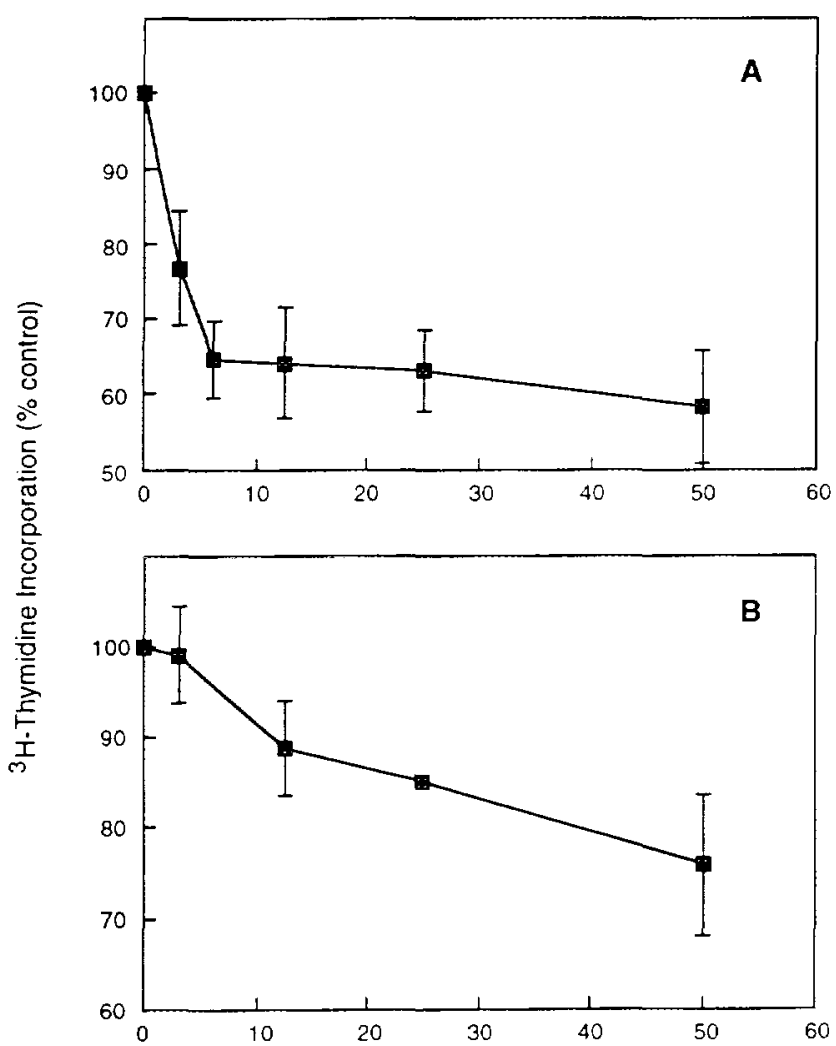

[BP3], $n M$

FIGURE 3. Dose dependent inhibition of MCF7 cell proliferation by IGF-BP3 in the absence and presence of $17 \mathrm{~B}$-estradiol. MCF7 cells were cultured with increasing concentrations of IGF-BP3 in the presence or absence of $0.1 \mathrm{nM} 17 \mathrm{~B}$-estradiol. Estradiol stimulated $\left[{ }^{3} \mathrm{H}\right]$ thymidine incorporation was $178 \pm 13 \%$ that observed in the absence of estradiol after 2 days of treatment. Data from 3 paired experiments are presented separately for the estradiol-free (A) and estradiolcontaining (B) conditions, and values obtained in the presence IGF-BP3 are expressed as the mean percentage \pm SEM of the value obtained in the IGF-BP3-free condition, as described in Results.

$(8,13.14)$, this is the first report of antagonism of estradiol-stimulated cell proliferation by an IGF binding protein. The demonstration that IGF-BP3 can inhibit serum stimulated MCF7 cell proliferation, both in the absence and presence of estrogens, is significant given that pharmaceutical agents such as antiestrogens $(8)$ and retinoids $(15,16)$ have been shown to have antiproliferative effects and to increase IGF-BP3 levels in the conditioned media of MCF7 cells. Our data are compatible with the hypothesis that these agents act in part by activating an IGFBP3 growth inhibitory autocrine loop. Furthermore, as antiestrogens increase expression of TGFB in breast cancer cells (17), and TGFB has been shown to induce IGF-BP3 production by fibroblasts (18) an additional antiestrogen modulated IGF-BP3 inhibitory paracrine loop may exist in vivo. 
In the serum containing experimental system we have employed, ligands for the type I IGF receptor are present. We therefore cannot distinguish between the possibilities that (a) IGFBP3 reduces estradiol-stimulated proliferation by a direct, IGF-independent growth inhibitory action $(9,19,20)$ or (b) that estrogen-stimulated proliferation of MCF7 cells is mediated, at least in part, by increased responsiveness to exogenous IGFs $(8,13)$, in which case IGF-BP3 could attenuate estradiol-stimulated proliferation by decreasing the concentration of free IGFs available for receptor binding. A third possibility is that exogenous IGF-BP3 (and antiestrogen-stimulated IGF-BP3) act to inhibit cell proliferation by interrupting a stimulatory IGF-II autocrine loop (21). IGF-BP3 binding to IGF-II produced by neoplastic cells would prevent IGF-II interaction with the type I IGF receptor, and in vivo, this mechanism could also block stimulatory IGF-I paracrine loops involved in stromal-neoplastic cell interactions (22).

There are multiple levels at which antiestrogens interact with the IGF system. Antiestrogens have been shown to modulate the expression of type I IGF receptors in breast cancer cells (13), the circulating IGF-I concentration (23-25) as well as the expression of IGF-I by liver and other tissues $(26,27)$. Regardless of the mechanism of IGF-BP3 inhibition of MCF7 cells, our results are compatible with the hypothesis that IGF-BP3 mediates in part certain growth-inhibitory actions of retinoids and antiestrogens.

\section{ACKNOWLEDGMENTS}

We would like to thank Chris Maack, Celltrix Pharmaceuticals, Santa Clara, California for the rhIGF-BP3. This work was supported by a grant to M.P. from the National Cancer Institute of Canada.

\section{REFERENCES}

1. Pollak, M.N., Polychronakos, C., Yousefi, S., and Richard, M. (1988) Biochem. Biophys. Res. Commun. 154, 326-331.

2. Peyrat, J.P. and Bonneterre, J. (1992) Breast Cancer Res. Treat. 22, 59-67.

3. Sara, V.R. and Hall, K. (1990) Phys. Rev. 70, 591-614.

4. Rechler, M.M. and Brown, A.L. (1992) Growth Regulation 2, 55-68.

5. De Leon, D.D., Wilson, D.M., Bakker, B., Lamsom, G., Hintz, R.L., and Rosenfeld, R.G. (1989) Mol. Endo. 3, 567-574.

6. Clemmons, D.R., Camacho-Hubner, C., Coronado, E., and Osborne, C.K. (1990) Endo. $127,2679-2686$.

7. Yee, D., Favoni, R.E., Lippman, M.E., and Powell, D.R. (1991) Breast Cancer Res. Treat. 18, 3-10.

8. Pratt, S.E. and Pollak, M.N. (1993) Cancer Res. 53, 5193-5198.

9. Cohen, P., Lamson, G., Okajima, T., and Rosenfeld, R.G. (1993) Mol. Endo. 7, 380-386.

10. Knauer, D.J. and Smith, G.L. (1980) Proc. Natl. Acad. Sci. USA 77, 7252-7256.

11. Blum, W.F., Jenne, E.W., Reppin, R., Kietzmann, K., Ranke, M.B., and Bierich, J.R. (1989) Endo. 125, 766-772. 
12. De Mellow, J.S.M. and Baxter, R.C. (1988) Biochem. Biophys. Res. Comm. 156, 199-204.

13. Stewart, A.J., Johnson, M.D., May, F.E.B., and Westley, B.R. (1990) J. Biol. Chem. 265 , 21172-21178.

14. Thorsen, T., Lahooti, H., Rasmussen, M., and Aakvaag, A. (1992) J. Steroid Biochem. Mol. Biol. 41, 537-540.

15. Adamo, M.L., Shao, Z., Lanau, F., Chen, J.C., Clemmons, D.R., Roberts,C.T., LeRoith, D., and Fontana, J.A. (1992) Endo. 131, 1858-1866.

16. Fontana, J.A., Burrows-Mezu, A., Clemmons, D.R., and LeRoith, D. (1991) Endo. 128. 1115-1122.

17. Knabbe, C., Lippman, M.E., Wakefield, L.M., Flanders, K.C., Kasid, A., Derynck, R., and Dickson, R.B. (1987) Cell 48, 417-428.

18. Martin, J.L. and Baxter, R.C. (1991) Endo. 128, 1425-1433.

19. Oh, Y., Muller, H.L., Lamson, G., and Rosenfeld, R.G. (1993) J. Biol. Chem. 268, 14964-14971.

20. Liu, L., Delbe, J., Blat, C., Zapf, J., and Harel, L. (1992) J. Cell Physiol. 153, 15-21.

21. Osborne, C.K., Coronado, E.B., Kitten, L.J., Arteaga, C.I., Fuqua, S.A., Ramasharma, K., Marshall, M., and Li, C.H. (1989) Mol. Endo. 3, 1701-1709.

22. Yee, D., Paik, S., Lebovic, G.S., Marcus, R.R., Favoni, R.E., Cullen, K.J., Lippman, M.E., and Rosen, N. (1989) Mol. Endo. 3, 519-517.

23. Pollak, M.N., Costantino, J., Polychronakos, C., Blauer, S., Guyda, H., Redmond, C., Fisher, B., and Margolese, R. (1990) JNCI 82, 1693-1697.

24. Pollak, M.N., Huynh, H.T., and Lefebvre, S. (1992) Breast Cancer Res. Treat. 22, 91-100.

25. Pollak, M.N. (1993) In Adjuvant Therapy of Cancer VII (S.E. Salmon, Ed.), pp. 43-54. Lippincott, Philadelphia.

26. Huynh, H.T., Tetenes, E., Wallace, L., and Pollak, M. (1993) Cancer Res. 53, 1727-1730.

27. Huynh, H.T. and Pollak, M.N. (1993) Cancer Res. 53, 5585-5588. 